\title{
Chapter 14 \\ Trans-knowledge? Geography, Mobility, and Knowledge in Transnational Education
}

\author{
Johanna L. Waters and Maggi Leung
}

TNE [Transnational Education] programs are sold as time-space compressors, extending the spatial reach of immobile consumers (potential students) who aspire to tap cultural and social capital nurtured at universities (what Brinton [2000] has termed "institutional social capital") located at the core of the global knowledge economy.

(Leung \& Waters, 2013, p. 1)

Is there anything more mobile and less sticky than the knowledge imparted and created through transnational higher education (TNE)? The very notion of transnationalism implies an inherent mobility and fluidity - a process at ease with geographical distance and difference. By definition, the mobility of knowledge lies at the heart of TNE; it crosses, transects, and overcomes the parochialism and embeddedness of national education systems, to deliver educational programs to students who are both culturally and spatially removed from home. TNE provides, we argue, a fascinating case study of the mobility of knowledge, not least because it lies at the forefront of recent, hugely significant developments in the internationalization of higher education (HE), globally (Department for Business, Innovation and Skills [BIS], 2011; Bone, 2010). And yet, very little is known about the geographies of knowledge within this innovative form of teaching and learning (Leung \& Waters, 2013a; Waters \& Leung, 2013b).

In this chapter, we critically examine the mobility of knowledge as a consequence of the growth and expansion of TNE, focusing specifically on the movement of academic programs between the United Kingdom and Hong Kong, whereby U.K. universities are the providers and Hong Kong higher education institutions (HEI)

\footnotetext{
J.L. Waters $(\square)$

Department of Human Geography, School of Geography and the Environment, University of Oxford, OX1 2JD Oxford, UK

e-mail: johanna.waters@conted.ox.ac.uk

M. Leung

Department of Human Geography and Spatial Planning, Utrecht University, 3512 JE Utrecht, The Netherlands
} 
the hosts. ${ }^{1}$ We seek to address a number of questions, including: (a) What is knowledge in relation to TNE? (b) How important is knowledge within TNE? (c) How well does knowledge travel through TNE? (d) What are the implications of these findings for TNE (particularly for students and the providers of transnational forms of education)?

The chapter draws on the results of a recent research project (2009-2011), in which we undertook a qualitative examination of the transnationalization of higher education in contemporary Hong Kong, with a particular focus on U.K. (university) providers. In our project, we conducted 70 in-depth interviews with students (38) and graduates (32) in Hong Kong, but also acquired substantial input from 18 British universities (the providers of TNE) and nine employers and recruiters. Some 36 British universities offer over 600 different degree courses (at the bachelor's, master's, and PhD levels) in Hong Kong at the present time, and the number of programs continues to grow (British Council, 2010). The United Kingdom has 388,135 offshore students globally, compared to over two million students in U.K. higher education (HE) in total (British Council, 2010), but British universities are particularly prominent in Hong Kong, where over $70 \%$ of all TNE is provided by British higher education institutions (HEIs), followed by Australia at around $20 \%$ (Education Bureau, 2012). The United Kingdom is, therefore, an established presence in the Hong Kong educational landscape.

A simple definition of transnational education is provided by McBurnie and Ziguras (2007): "[in TNE] learners are located in a country other than the one in which the awarding institution is based" (p. 21). Such offshoring of education is:

only possible because higher education is now able to traverse time and space to an extent never before achievable. For two decades now, transnational programs have been at the experimental leading edge of efforts to store and standardize curricula to allow for the delivery of a replicated curriculum to multiple student groups at different times in different places by different teaching staff. (p. 2)

In other words, TNE involves the capturing, storing, and conveying of academic knowledge. Basic teaching materials are transported (in hard or electronic format) and ideas on how to run the programs are often exchanged (between the provider and the host institution). Some transnational negotiation is inevitable (rarely does the host institution embrace and adopt the teaching ideas of the foreign university wholesale and without question). Core textbooks are physically transported, as are exam scripts for marking. Transnational relationships are built-between the provider and the host of the programs and, of course, between the provider and their overseas students. Usually, TNE involves the physical mobility of academic staff (to teach, to examine, or to provide a "Western" presence at graduation ceremonies), as

\footnotetext{
${ }^{1}$ In this chapter, we use the following terms: provider refers to the country or academic institution awarding the degree or other qualification in TNE. In the case of our research, these are U.K. HEIs. Host refers to the country or institution delivering the academic programs (with respect to our research, these are HEIs or other educational establishments in Hong Kong).
} 
we will expand upon below. It should not be assumed, however, that the "traversing of time and space" through TNE, as described by McBurnie and Ziguras (2007), is easy or necessarily wholly successful.

An idealistic portrait of TNE would depict the unproblematic transplanting of ideas, theories, and empirical realities from one nation-state (continent or region of the world) to another. This, indeed, is how many of the marketing materials relating to TNE portray their programs (Leung \& Waters, 2013). When necessary, those delivering these academic programs will tailor the materials to their local audience-to provide insight and offer examples students can better identify with. Most of the knowledge contained in the courses, however, is assumed to be generic enough to travel and be understood by a foreign audience. There will be very little in the way of cultural barriers to students' understanding and the delivery of materials in English will be straightforward, because students will be expected to have an adequate grasp of the language of instruction.

As we will elaborate below, our research on TNE in Hong Kong, however, suggests some problems with this ideal representation. The embodied realities of knowledge transfer and exchange in TNE include some significant cultural challenges because of a divergence between the provider and host institutions regarding their academic practices and expectations. The courses often involve students with an inadequate grasp of the English language and local lecturers or tutors hired to deliver these programs widely reverting to Cantonese (for ease of teaching) and eschewing English. Many of the students we interviewed complained that empirical examples were far too embedded in a U.K. context to be relevant to their situation in Hong Kong; conversely, others, who were hoping for a British experience, complained about the lack of this within their program.

Our research left us pondering the following questions: how much thought do the providers of TNE put into the spatiality of knowledge transfer and exchange? To what extent do they critically engage with the geography of their practices, and with what consequences? We refer here to our data, as well as some previously published work on this topic, to address these questions (see Leung \& Waters, 2013; Waters \& Leung, 2013a, 2013b). We begin, however, with a brief discussion of some of the conceptual ideas underpinning debates in geography around mobility and knowledge.

\section{Geography, Mobility, and Knowledge}

Within geography, knowledge has been widely discussed in relation to the impact of information and communication technologies (ICTs) upon its transfer. Debates have tended to polarize around two competing claims: those who argue that ICTs have succeeded in overcoming the friction of distance and enabled long-distance knowledge transfers to occur; and those who (conversely) have emphasized the inevitable stickiness and social embeddedness of (particularly tacit) knowledge, 
wherein face-to-face interactions remain essential for successful knowledge transfer and exchange to take place (see Glücker, Meusburger, \& Meskioui [2013] on the complexities of defining different types of knowledge). Amin (2003), for example, has argued in favor of claims that technology has greatly facilitated knowledge transfer. He has written: "that relational proximity is also possible in distantiated networks, through mobility and a series of other technologies of contact and translation" (Amin, 2003, p. 116). In his view, "nearness" does not only connote "spatial proximity," but can be achieved in other (non-territorial) ways, which can include (in the context of international firms): "translation, travel, shared routines, talk, common passions, base standards, brokers, epistemic and community bonding, and the ordering and orientation provided by files, documents, codes, common software and so on" (Amin, 2003, p. 127). Such things, Amin opines, are not necessarily achieved through physical spatial proximity. A similar line of argument is pursued by Faulconbridge (2006), who, on the basis of his research on professional service firms, argues that tacit knowledge "can have global geographies when knowledge management practices focus on reproducing rather than transferring knowledge across space" (p. 517) (see also earlier work by Beaverstock, 2004, 2005, for a precursor to these arguments). This, we suggest, may hold some relevance for how we understand the mobility of knowledge within TNE. Within TNE, knowledge may, in fact, be reproduced rather than directly and unproblematically transferred. The reproduction of knowledge requires, at its heart, an understanding of that knowledge. Faulconbridge (2006) describes the "global stretching" of knowledge in professional service firms, and argues that while concepts of "local stickiness" invoked in relation to tacit knowledge are useful for emphasizing the difficulties that sometimes arise when attempting to transfer knowledge within and between organizations, it is also necessary to recognize that learning may be spatially stretched beyond scale-defined limits. There is, Faulconbridge asserts, an important difference between knowledge transfer and what he terms the social production of new knowledge; globally stretched or spatially distantiated learning, he argues actually involves the social production of new knowledge and not knowledge transfer (as it is conventionally understood).

A counterview on geography and knowledge transfer has been elaborated by Morgan (2004), who described the "exaggerated death of geography" (p. 3). ICTs, he argues, do not enable the unproblematic transferring of ideas over space. Those claiming that ICTs have such "distance-destroying capacity ... [are] ... conflating spatial reach with social depth" (p. 3). This is the difference between information and understanding - the former can be transferred using technology over space, whereas the latter necessitates face-to-face interaction and exchange. This idea reflects wider debates in economic geography, in which it is claimed that tacit knowledge is "locationally sticky" (Amin, 2003). Gertler (2003) makes the following related claims about knowledge transfer:

learning involving tacit knowledge transfer, when attempted across major institutionalcontextual boundaries, will be subject to formidable obstacles, even in the presence of substantial corporate wealth and resources ... The upshot is that transcending ... spatial 
proximity may be possible, but it will also be difficult and expensive, because of the fundamentally different institutional environments involved ... Technological fixes ... may not be sufficient to overcome these obstacles. (p. 95)

These claims, we argue, have significant resonance with our research findings relating to TNE enacted between the United Kingdom and Hong Kong. TNE, more generally, invariably involves "fundamentally different institutional environments" (Gertler, 2003, p. 95)—culturally, socially, and linguistically. However, it remains a moot point as to whether the institutions involved have devoted the necessary resources to overcome these obstacles. TNE is often seen as a way of generating extra revenue for universities and so saving (not spending) money is a primary concern.

Geographers have also written about the role that migrants play in knowledge transfer, and Alan Williams's work has been instrumental in this regard. Williams draws upon Blacker's (2002) typology, which distinguishes between different types of knowledge: embrained, embodied, encultured, embedded, and encoded-some of which are inherently more mobile than are others. ${ }^{2}$ The most mobile of all, Williams claims, is encoded knowledge - as found in text books and manuals. Meusburger (2013), however, makes the point that simply making knowledge accessible does not make it understood - understanding is the key to true mobility. Embrained and embodied knowledge have a corporeal mobility, in that they will move with and within the migrant. Finally, encultured and embedded forms of knowledge are, in contrast, relatively immovable, as they represent "relational knowledge, grounded in the institutionally specific relationships between individuals" (Williams, 2006, p. 591). The question this raises for us is this: What types of knowledge (as signified here) does TNE actually represent? In theory, it should be the epitome of encoded academic knowledge - through the mobility of text books and intellectual ideas contained within academic journals. Different models of TNE, however, will involve a different balance in the types of knowledge represented. Thus, embodied knowledge will be far more prevalent when a flying faculty model is deployed, than when a franchise model is used. ${ }^{3}$

More generally, Williams (2006) argues that the movement of knowledge through migration is perhaps best conceptualized as translation. "Migrants," he writes, "have distinctive roles as translators of knowledge ... The notion of translation takes us beyond simplistic ideas about transferring immutable knowledge, and leads to consideration of knowledge creation" (p. 593). This invokes the ideas of Faulconbridge (2006, p. 533) regarding "the social production of new knowledge"-knowledge is

\footnotetext{
${ }^{2}$ Embrained knowledge describes cognitive and conceptual skills, while embodied knowledge refers to physical experience (practical work within a particular context). Encultured knowledge describes shared cultural meanings and understandings and embedded knowledge is found within particular contexts. Finally, encoded knowledge refers to signs and symbols found in books, manuals, websites, and policy reports.

${ }^{3}$ The flying faculty model refers to when staff from the home institution fly out at intervals to teach their program, whereas a franchise model involves the home institution selling the degree program to the host institution, which is then responsible for delivering it.
} 
largely reproduced rather than transferred. We explore, below, the extent to which knowledge transfer in TNE can be considered translation or knowledge creation.

Louise Ackers (2012) has examined "the relationship between human mobility and knowledge transfer processes" (p. 131) directly. She describes a move, in the literature, away from emphasizing long-term embodied migration (captured by the concept of brain drain) as "the value of short stays and the substitution of physical co-presence with virtual stays (providing the opportunity for "disembodied" knowledge transfers) became recognized as key mechanisms for relationship-building and knowledge transfer" (p. 133).

In the proceeding sections and in relation to these debates, we draw upon our data to address the following issues. First, we consider definitions of knowledge and transnational in relation to TNE. What does knowledge in TNE actually represent, and is it the same as capital? This is significant, because much of the extant literature on international education discusses the capital (not knowledge) that students acquire. There must also be, we argue, something meaningful about the transnational element of TNE. We discuss the possible interpretations of transnational in this context. Next, we move on to consider the process of knowledge transfer through TNE, examining the moving of program content. Two issues arise in relation to this-(a) the duplication of content in other (associate degree or higher diploma) courses; (b) the use of British contexts for examples and case studies. The next section then considers the subject of capital more directly, drawing upon other published papers to examine the extent to which TNE imparts cultural and social capital (Bourdieu, 1986) (as opposed to knowledge in its more traditional sense). The final substantive section of the chapter discusses how (successfully) knowledge (in its different forms and including capital) is transferred over space through TNE. Here, issues around language and different models of delivery are particularly pertinent. We also, in conclusion, suggest some ways in which knowledge transfer within TNE might be enhanced.

\section{Knowledge, Transnationalism, and TNE}

It should go without saying that the primary purpose of education, of any kind, is the imparting of knowledge and, to a lesser extent, knowledge creation. In other words, knowledge must be at the center of TNE. It is assumed that students enroll in a particular program (in our research, these were largely degree programs-both undergraduate and master's) with the intention of acquiring knowledge about a subject matter. The majority of TNE courses presently offered in Hong Kong involve some sort of business-related subject: for example, a bachelor of arts (with honors) in applied business, business information technology, international business management, business administration and management, or business and law. As explicated in Jöns (2007), this indicates not only different demands but also different 
possibilities with regard to the mobility of different types of knowledge. There is seen to be a need for transnational business knowledge and this may, in fact, travel more easily than humanities or social science knowledge. (Humanities programs are almost non-existent, and social science programs are very rare). These courses offer a mix of encoded knowledge (international business theory and principles) and encultured and embedded knowledge (in the U.K. and Hong Kong business environments) while also developing, in students, embrained knowledge (Blacker, 2002).

However, perhaps surprisingly, very few of our research subjects (students and graduates of TNE programs in Hong Kong) discussed their thirst for knowledge. Rather, they widely articulated a far more instrumental objective-to obtain a degree, as the following quotations suggest:

The only purpose of having this degree was to provide me with an entry ticket for meeting the minimum requirement as a degree holder. (Interviewee 6, graduated with a top-up ${ }^{4}$ degree in 2007)

The degree might not be good enough, but at least I could have a certificate. If you saw a job with "university graduate" as its requirement, you would be brave enough to send your application. Without this top-up degree we wouldn't even apply. (Interviewee 8, has almost finished a one-year top-up degree)

Employability considerations were fundamental, and the "ticket" was "a degree" and not a degree in a particular subject, nor the acquisition of a particular set of skills. Thus, our findings would seem to support other work on the aims and intentions of international students indicating that strategic and instrumental concerns about employment far outweigh any considerations about the acquisition of knowledge (Waters, 2008). This work largely asserts that contemporary (international) students are concerned not with the knowledge they will gain through a particular degree program, but with the capital they will acquire (Brooks \& Waters, 2011; Findlay, King, Smith, Geddes, \& Skeldon, 2012; Ong, 1999; Waters, 2006). However, we also observe below that this may relate to short-term rather than longer-term time frames. The value to be found in specific degree-related knowledge and social capital may develop over time, whereas cultural capital may indicate more short-term and immediate gains or rewards. Here, we are drawing heavily on the work of sociologist Pierre Bourdieu (1984, 1986); his definitions of capital have become axiomatic within work on the sociology of education.

Indeed, what our research participants were referring to was the perceived importance of institutional cultural capital - the symbolic power of the university degree and the practical power of the degree certificate (Bourdieu, 1986). And this brings us to consider the relationship between knowledge and capital, and to ask: Are knowledge and capital interchangeable when it comes to transnational education?

\footnotetext{
${ }^{4}$ In TNE, top-up refers to the fact that students in TNE undergraduate courses will have been required to complete either an associate degree or a higher diploma at a local tertiary institution, before transferring into the overseas program. They are supposed to be topping up this earlier qualification to degree level. Consequently, TNE top-up degrees are usually only 1-2 years in duration.
} 
Definitionally, there are clear differences between them: The importance of capital lies in its symbolism and its ability to be converted into something of value (e.g., employment or money). Knowledge, on the other hand, is supposed to be of value in and of itself. Both, however, can be accumulated over time. Cultural capital (particularly embodied cultural capital) implies a degree of know-how that clearly involves knowledge of sorts. Social capital, on the other hand, refers to the extent and quality of one's social relationships, and the more people you know, the more extensive (and therefore valuable) your social capital. Therefore social capital, too, involves knowledge, but is at the same time more than just knowledge. However, we are primarily interested in whether knowledge and capital are interchangeable in the particular context of transnational education (as opposed to more generally). And, in relation to TNE, it is legitimate to argue that they are. Students make little or no distinction between the cultural and social capital they are expecting to acquire in a TNE degree course, and the knowledge that they are anticipating accumulating (in the short term, at least). As described above, actual encoded knowledge would appear to be of very low immediate priority for students seeking to study in a transnational program. Far more important (we have deduced from our data) are the following: (a) gaining a university degree (any university degree); (b) gaining a degree from a university that an employer might recognize (the symbolic importance of the university's reputation); (c) building social capital (during the degree course and afterwards through alumni activities). Acquiring knowledge, per se, is a relatively minor concern. In this chapter, therefore, we consider capital alongside (and as a subset of) knowledge.

When addressing definitional issues, it is also necessary to consider the difference that transnationalism makes to the transfer of knowledge in these higher education contexts. Transnationalism, as it has come to be understood within a substantial body of academic work over the past two decades, implies a fluid, dynamic, constant movement of people, objects and ideas back and forth between a home and a host nation, to the extent that the distinction between home and host becomes necessarily blurred (e.g., Basch, Glick Schiller, \& Szanton Blanc, 1994). "Trans" evokes an ease of geographical mobility. Transnational education, as we have indicated above, implies an ongoing transaction or interaction between the home, or provider, institution and the host, or deliverer. However, the extent to which this term is an accurate description of the types of interactions that take place in TNE is questionable. For one, interactions between the home and host institution tend not to be continuous, but rather focused around certain times of the year or cycles in the academic term. ICTs are key to many of these exchanges, as face-to-face meetings occur, at best, two or three times a year. Second, most of the movement seems to be one-way-that is, from the home to the host institution. Very little mobility (whether of people, products, or ideas) would seem to occur from the host to the home nation or institution (with the exception sometimes of students' work for marking). This, again, leads us to question the appropriateness of the term transnational (education), which tends to imply a two-way flow. Perhaps the most transnational element of these programs is the home staff who teach in them, although this is not uniformly applicable-many TNE programs use a franchise model that employs local lecturers to deliver most, if 
not all of the course. We continue in the following to explore the extent to which transnationalism is apparent within the TNE programs we have examined.

\section{Moving Ideas: The Transfer of Program Content}

Because we're flying faculty we can't really offer a wide range of electives, so we do tend to fix the programs so students will have studied these modules, but it's based entirely on the U.K. program. So our U.K. modules will be in there-we'll have selected the core option, we'll have selected an appropriate elective. (U.K. HEI, Interview 5)

In Hong Kong, it is stipulated that TNE programs must be offered at the same time within the home country or institution. In principle, the students in Hong Kong are expected to graduate with the same knowledge and experience as their British counterparts. On graduation, they will receive an identical degree certificate. The mobility of program content is, consequently, essential. As described in the quotation above, however, a flying faculty model (and the resources this demands) makes it impossible for students in Hong Kong to have the same number of optional courses within a program as U.K.-based students do. It is just simply impractical. Interestingly, program content can and often does evolve over time (consequently decreasing the transnational element), as another U.K. university representative describes:

To begin with there was quite a close liaison between the module tutors at X [U.K.] university and the module tutors delivering the program in Hong Kong. That is to say, the curriculum and the texts and the references the students were using were either identical, or if they weren't, then the module tutors here [in the United Kingdom] had to agree to any changes to the teaching program in Hong Kong. In other words, there was quite a careful policing of what was being delivered in Hong Kong by academic colleagues here in X [U.K. university]. Now over the years, and perhaps in the last four or five years since I have been involved, that rather close scrutiny has to a large extent been diluted ... It was based upon the success of the first five or six years of the program, and the feeling emerged that, first of all, colleagues in Hong Kong were more than competent to develop the curriculum and to develop assignments and develop assessments that were more removed from what was being delivered in X [U.K. university] . . . We gave to colleagues in Hong Kong far more autonomy to teach, to develop, to assess and to monitor their own delivery and their program. So it was still very much an X [U.K. university] degree, which I think the students found attractive (or do find attractive), but we delegated to colleagues in Hong Kong far more responsibility for what they were doing, especially because most, if not all of the modules were contextualized through the Hong Kong business environment. Part of it [the delegation of responsibility] arose because, I think, colleagues in Hong Kong were finding U.K.-based or Western-based case studies perhaps inappropriate to the Hong Kong business scene and the Hong Kong business culture. (U.K. HEI, Interview 3)

As this quotation illustrates well, the extent of home involvement in knowledge production and exchange is not static, but changes, with implications for the extent to which course content can be described as transnational. The U.K. HEI representative says it is "still a U.K. university degree," but as control over the course content is increasingly given to the Hong Kong hosts, is this in name only? He also here 
makes reference to the appropriateness of U.K.-based case studies within many business-type degree programs, an issue that was also raised again and again by student and graduate interviewees. Most of them found the use of U.K. examples to be, at best, uninteresting and at worst, irrelevant. However, we found an intriguing counter-example in Interviewee 15, who was required in her TNE course to study the U.K. tax system ("Hong Kong has its own tax system"). Surprisingly, this knowledge proved useful on one particular occasion, when she recently worked for an Indian company with a branch in the United Kingdom:

For instance, colleagues would ask me what is meant by Value Added Tax, or some tax that does not exist in Hong Kong. At that moment, I would feel that what I learned was useful, although I have not had many of these kinds of moments! (Interviewee 15)

Another issue raised by interviewees with regard to program content concerned the duplication of materials and, in some cases, lecturers. Several students and graduates reported that much of the material learned in their TNE program duplicated work they had already covered (usually the previous year) in their higher diploma or associate degree. ${ }^{5}$ Interviewee 26 claimed:

The knowledge taught [on the TNE program] was the same as that I learned in my higher diploma course. I could simply use my study notes from my higher diploma course for revision for my exams in this degree course.

The result, some claimed, was a very similar "learning experience," because many of their TNE program teachers had also taught them in their higher diploma or associate degree courses. Edward Lee: "Actually, all the courses were lectured by local teachers who also taught us in my associate degree." In many cases, the Hong Kong institutions delivering the TNE program employ locally sourced lecturers to teach it, and (coincidentally) these are often the same individuals who teach in their associate degree or higher diploma courses. As we go on to discuss, this has implications for the kinds of social capital students are able to acquire in TNE programs (Waters \& Leung, 2013a).

Positive differences in the nature of knowledge on TNE degree programs vis-avis the higher diploma/associate degree were also noted by a minority of interviewees, however:

For the higher diploma, most of the time we had to recite something. For the top-up degree we couldn't simply recite the materials but had to think ... A degree should be like this. If it is not, I would be afraid. For a degree, we should think more. (Interviewee 17, has almost completed a one-year top-up program in marketing)

In this case, the knowledge acquired in the degree felt more advanced than previous knowledge attained in lower degrees or diplomas.

\footnotetext{
${ }^{5}$ The majority of students will have studied for a higher diploma or associate degree in the year prior to embarking on the transnational program. Usually, this will have been undertaken at a local tertiary institute. This qualification is unconnected to the TNE program that follows, and thus duplication is an issue.
} 


\title{
The Transfer of Different Forms of Capital
}

The distribution of the different types and subtypes of capital at any given moment in time represents the ... structure of the social world, i.e., the set of constraints, inscribed in the very reality of that world ... determining the chances of success... (Bourdieu, 1986, p. 242)

As discussed in this quotation, in relation to TNE, it makes sense to characterize capital as a subtype of knowledge acquired through education, not least because students themselves did not draw a distinction between capital and education. We therefore briefly discuss transnational capital as a form of knowledge transfer found within TNE. Pierre Bourdieu (1986, p. 243) famously described three main forms of capital: economic ("which is immediately and directly convertible into money and may be institutionalized in the form of property rights"), cultural ("which is convertible, on certain conditions, into economic capital and may be institutionalized in the form of educational qualifications"), and social ("made up of social obligations, which is convertible, in certain conditions, into economic capital"). We discussed in an earlier publication (Waters \& Leung, 2013a) the relationship between TNE in Hong Kong and the development of institutional social capital (Brinton, 2000) among students. According to Bourdieu (1986), social capital is

\begin{abstract}
the aggregate of the actual or potential resources which are linked to the possession of a durable network of more or less institutionalized relationships of mutual acquaintance and recognition —or in other words, to membership in a group-which provides each of its members with the backing of the collectivity-owned capital, a "credential" which entitles them to credit, in the various senses of the word. These relationships may exist only in the practical state, in material and/or symbolic exchanges which help to maintain them. They may also be socially instituted and guaranteed by the application of a common name (e.g., a family or of a school) ... . (pp. 248-249)
\end{abstract}

The common name can be a school or a university, with significant social implications for individuals for whom the development of social capital is somehow curtailed. In our paper, we argued that, for various reasons, students in U.K. TNE programs in Hong Kong were unable fully to develop the kinds of institutional social capital one might expect from a university experience. Space prohibits a detailed discussion of them here. However, the following points are pertinent to this chapter's discussion. The development of social capital is limited because (a) teaching on TNE programs often takes place away from the main university campus (usually in a downtown location); (b) students therefore miss out on the spatial advantages that a campus has to offer, including the close proximity of other students; (c) limited or no contact with U.K. teaching staff diminishes the transnational social capital available; (d) alumni associations are significantly underdeveloped; and, finally, (e) top-up degrees can be over in as little as 1 year and students complained that this did not allow enough time for social capital to be developed. In Leung and Waters (2013) we also make a specific argument about space and place in relation to TNE-we stress that students have extremely grounded experiences of learning (from the physical location of where teaching takes place, to the use of 
local lecturers, to the use of local examples in the teaching), and we juxtapose this with the space-conquering claims of the TNE providers.

However, some capital within TNE programs often does travel, in different ways. This can include the British academic staff members, who make the regular trips out to Hong Kong and have (some, if limited) contact with the students, and, as the quotation below describes, the U.K. university's brand name. One interviewee said:

\footnotetext{
One of the things they [the students] say is they like having the British academics out there, and they always want photographs with you and stuff like that. And at graduation they always want [their photograph with you]. I mean, one of the things they've said to me this year, and we've tried to do something about it, is that they've said 'we need to feel part of $\mathrm{X}$ [U.K. university], we want to be $\mathrm{X}$ students, and not just $\mathrm{Y}$ [Hong Kong university] students. So you know, we've done small things like send them out $X$ [letter headed] paper and $X$ stuff, you know. We try to do that. (U.K. HEI, Interview 9)
}

This describes a rare example of the U.K. institution being very sensitive to students' needs and their desire to attain some cultural capital from the home university - and acting upon this understanding. According to Ackers (2012), short stays can "play a very important role in promoting knowledge transfer" (p. 13) and so it is feasible that these brief trips by U.K. academics to teach in TNE programs do promote transnational knowledge transfer.

\section{How (And the Limits to How) Knowledge Is Transferred in TNE}

In this last section we address two key issues affecting how knowledge is actually transferred through TNE (in practice) and how these relate to language (and understanding), and the mobility of U.K. academics.

\section{Language Issues}

As discussed in depth in Waters and Leung (2013b), students undertaking British TNE programs in Hong Kong are often not as fluent in English as might be assumed and many, as was reported by them to us, struggled to understand when subjects were taught by British academics.

No one would challenge them (the U.K. lecturers) because the lessons were conducted in English. We were not confident with our English proficiency. I am not sure if someone has ever challenged them, but I would not. My English is not very good. This may be a weakness when compared with graduates from local universities. (Interviewee 26, has almost completed a one-year top-up program)

Thus, although United Kingdom academics may be seen to embody transnational knowledge, this knowledge is not being successfully transferred (in many cases) to 
students, who lack the essential element of understanding. This important issue points to problems with the understanding of knowledge and not just the transplanting of information, as noted by Morgan (2004), who is careful to distinguish between these two concepts (see also work by Meusburger, 2013). For many students (it would seem), understanding is the main challenge when it comes to knowledge transfer. Local lecturers employed to teach these courses attempt to remedy this problem somewhat by reverting to Cantonese and dispensing with English altogether. This has come to the attention of some U.K. universities:

Everything is supposed to be taught in English. I get the impression that sometimes it's easier for the staff to just deliver it in whatever. But everything is written, all the assessments are in English, everything, all our stuff is in English. And to be honest, I think ... quite a few of the staff do it ... when things are getting a bit difficult, sometimes they revert to Cantonese (U.K. HEI, Interview 9)

So, while teaching in Cantonese could be seen as facilitating knowledge transfer, this approach inevitably also diminishes the transnational element of the program (which is supposed to include English language medium teaching) and, of course, attenuates the cultural capital to be gained by being taught in (and improving one's proficiency in) English.

\section{Mobile Academics}

Transnational movements of academics shape the production and dissemination of knowledge and thus the geographies of contemporary knowledge economies. (Jöns, 2007, p. 97)

Geographer Heike Jöns (2007) is unequivocal in her claims regarding the significance of academic mobility (the international movements of scientists and scholars) to the contemporary knowledge economy (see also Ackers, 2012). It plays, she argues, a key role in (a) the internationalization of higher education; (b) the maintenance of a strong research capacity within universities and countries; and (c) the longer term development of important transnational social networks. Key to her argument is exploring the complex relationship between knowledge production and spatial movement. Here, we touch in brief upon some of her claims and make links to recent developments in transnational higher education.

To a greater or lesser extent, TNE does involve the transnational movement of academics and thus has the potential to contribute to significant social transformation, as highlighted by Jöns (above). As already noted, some programs are taught entirely by what has come to be called the flying faculty model. This was described to us by one U.K. academic responsible for administering their department's TNE programs in Hong Kong:

[Our programs] are taught solely by flying faculty, so they're solely our staff. XXX is taught in blocks over a semester, so they [U.K. staff] will go and teach the initial block over, say, four or five days, and then local tutors take over with a workshop and seminar support, and then our lecturers go back and do a revision session at the end ... [In our original model] they basically teach over eight days-it's over a nine day period, because they take the 
Thursday off. So they teach Saturday afternoon and early evening, Sunday all day, Monday, Tuesday, Wednesday evenings, Friday evening, and again Saturday afternoon/evening and Sunday all day. (U.K. HEI, Interview 5)

This particular academic department has about ten staff flying out at any one time:

"It is quite a lot of staff, yeah, and it is, it's very intensive, the flying faculty. It's quite resource heavy. But the students do seem to like it. It does seem to be a good selling point. It distinguishes our program from other programs that are maybe more of a franchise model.” (U.K. HEI, Interview 5)

This approach also, quite possibly, has an important role to play in the knowledge transfer process-Ackers's work on short-term stays within healthcare partnerships (between the United Kingdom and Uganda) suggests that "where the visits are well organized, prepared for in advance and form an integrated component of a mutually planned and coordinated project, they can play a very important role in promoting knowledge transfer" (Ackers, 2012, p. 13).

In a way, the problem when assessing the transnational movement of knowledge in TNE lies precisely with the huge diversity of approaches adopted by different institutions and programs within those institutions. The flying faculty model is the most hands on when it comes to transnational involvement and represents a high degree of embodied cultural and social capital. However, very few TNE programs deploy this model to the extent described here-many fly staff out to Hong Kong to introduce the program and for graduation at the end, with little or nothing in between. Others do not involve U.K. staff at all.

\section{Conclusions: So Where Is Knowledge in TNE?}

This chapter has considered if and how knowledge is transferred within transnational education. We began with the premise that TNE should, by its very nature, epitomize knowledge transference over space. In its idealized form, TNE indicates knowledge transported from one country to another, from one institutional environment to another, and from one cultural and social context to another. The recent momentous growth in TNE programs over the past decade suggests the overwhelming success of this process. Drawing upon our empirical data, however, we argue that in reality very little consideration has been given (by the providers of TNE) to the geography of knowledge transmission/exchange and (a wider issue) the geographies of institutionalized cultural capital. In this chapter we make several observations about knowledge transfer in TNE. Initially, however, a definition of knowledge transfer in relation to TNE is needed. First, it attempts to define what we mean by knowledge in relation to TNE. It would appear that knowledge is both created and translated in TNE (Faulconbridge, 2006) - knowledge creation is particularly apparent over time, as U.K. HEIs (for cost and other reasons) loosen their control over their programs and Hong Kong HEIs are given more control. We initiated a discussion of knowledge in relation to different forms of (institutionalized) capital, 
asking whether knowledge and capital could be seen as interchangeable when it comes to (transnational) education. We concluded that, on the basis of our data and the research of others on international students, yes, capital should usefully be conceived as a subset of knowledge within TNE (for students and immediate graduates, if not perhaps for individuals who have been in the workplace for some time). We then examined the transnational element of TNE and discussed the obvious limits to transnationalism within this form of long-distance education. These limits need to be better reflected in TNE marketing and literature, which tends to assume the unproblematic transplanting of ideas and symbolic capital (Leung \& Waters, 2013). More generally, the transfer of knowledge and capital within TNE programs is hampered by language problems, structural problems with the programs themselves (for example, the absence of alumni associations and the tendency to teach students off campus), and the increasing propensity towards using a (cheaper) franchise model of teaching (as opposed to using flying faculty to deliver the course). According to Ackers (2012), short term stays, such as those practiced by some U.K. academics in Hong Kong, can be productive and actively promote knowledge transfer. However, such stays are, it would appear, increasingly rare within TNE, as more and more control is handed over to the Hong Kong partner. This is not necessarily a bad thing, with there being advantages of this model for students, but it raises questions about the transnational nature of knowledge in these circumstances, and the extent to which it is being transferred or created. When a flying faculty model is applied, the transfer of embodied knowledge is hampered by the use of lecturers' use of English, which is poorly understood by students. And yet, this model is clearly more fundamentally transnational in nature. Conversely, where a franchise model is deployed (with use of local staff), students gain better understanding of the materials (through use of Cantonese in teaching and use of local examples), and yet the transnational element is significantly attenuated. An open discussion among U.K. universities about the geography of the knowledge transfer process within TNE, as it currently stands, may result in a richer and more valuable experience for the students undertaking these programs.

Acknowledgements We gratefully acknowledge the generous financial support of the Economic and Social Research Council in the United Kingdom (RES-000-22-3000) and the Research Grants Council in Hong Kong. We also acknowledge the work of Yutin Ki, who conducted many of the interviews for this project.

\section{References}

Ackers, H. L. (2012). Mobilities and knowledge transfer: Understanding the contribution of volunteer stays to north-south healthcare partnerships. International Migration, 53, 131-147. doi:10.1111/j.1468-2435.2012.00773.x

Amin, A. (2003). Spaces of corporate learning. In J. A. Peck \& H. Wai-chung Yeung (Eds.), Remaking the global economy: Economic-geographical perspectives (pp. 114-129). London: Sage. 
Beaverstock, J. (2004). 'Managing across borders': Knowledge management and expatriation in professional service legal firms. Journal of Economic Geography, 4, 157-179. doi:10.1093/ jeg/4.2.157

Beaverstock, J. (2005). Transnational elites in the city: British highly-skilled inter-company transferees in New York City's financial district. Journal of ethnic and migration studies, 31, pp. 245-268. doi:10.1080/1369183042000339918

BIS (2011). Estimating the value to the UK of education exports. Department for Business, Innovation and Skills, BIS Research Paper no. 46. Retrieved from http://www.bis.gov.uk/ assets/BISCore/higher-education/docs/E/11-980-estimating-value-of-education-exports.pdf

Basch, L., Glick Schiller, N., \& Szanton Blanc, C. (1994). Nations unbound: Transnational projects, postcolonial predicaments, and deterritorialized nation-states. Amsterdam: Gordon and Breach.

Blacker, F. H. M. (2002). Knowledge, knowledge work and organizations: An overview and interpretation (reprinted). In N. Bontis \& C. W. Choo (Eds.), The strategic management of intellectual capital and organizational knowledge (pp. 47-64). New York: Oxford University Press.

Bone, D. (2010). Internationalisation of HE: A ten year view. Retrieved from http://webarchive. nationalarchives.gov.uk/tna/+/http://www.bis.gov.uk/wp-content/uploads/2009/10/ HE-Internationalisation-Bone.pdf

Bourdieu, P. (1984). Distinction: A social critique of the judgement of taste (R. Nice, Trans.). London: Routledge Kegan \& Paul.

Bourdieu, P. (1986). The forms of capital. In J. G. Richardson (Ed.), Handbook of theory and research for the sociology of education (pp. 241-258). New York: Greenwood Press.

Brinton, M. C. (2000). Social capital in the Japanese youth labor market: Labor market policy, schools, and norms. Policy Sciences, 33, 289-306. doi:10.1023/A:1004893624263

British Council (2010). The landscape of learning: Guide to UK qualifications in Hong Kong 2009-10. British Council and EDU Plus.

Brooks, R., \& Waters, J. (2011). Student mobilities, migration and the internationalization of higher education. Basingstoke: Palgrave Macmillan.

Education Bureau, Government of Hong Kong Special Administrative Region (2012). Statistical Information. Retrieved from http://www.edb.gov.hk

Faulconbridge, J. R. (2006). Stretching tacit knowledge beyond a local fix? Global spaces of learning in advertising professional service firms. Journal of Economic Geography, 6, 517-540. doi:10.1093/jeg/lbi023

Findlay, A. M., King, R., Smith, F. M., Geddes, A., \& Skeldon, R. (2012). World class? An investigation of globalisation, difference and international student mobility. Transactions of the Institute of British Geographers, 37, 118-131. doi:10.1111/j.1475-5661.2011.00454.x

Gertler, M. S. (2003). Tacit knowledge and the economic geography of context, or the undefinable tacitness of being (there). Journal of Economic Geography, 3, 75-99. doi:10.1093/jeg/3.1.75

Glückler, J., Meusburger, P., \& El Meskioui, M. (2013). Introduction: Knowledge and the geography of the economy. In P. Meusburger, J. Glückler, \& M. el Meskioui (Eds.), Knowledge and the economy (pp. 3-14). Knowledge and Space: Vol. 5. Dordrecht: Springer.

Jöns, H. (2007). Transnational mobility and the spaces of knowledge production: A comparison of global patterns, motivations and collaborations in different academic fields. Social Geography, 2, 97-114. doi:10.5194/sg-2-97-2007

Leung, M., \& Waters, J. L. (2013). British degrees made in Hong Kong: An enquiry into the role of space and place in transnational education. Asia Pacific Education Review, 14, 43-53. doi:10.1007/s12564-013-9250-4

McBurnie, G., \& Ziguras, C. (2007). Transnational education: Issues and trends in offshore higher education. Oxford: Routledge.

Meusburger, P. (2013). Relations between knowledge and economic development: Some methodological considerations. In P. Meusburger, J. Glückler, \& M. el Meskioui (Eds.), Knowledge and the economy (15-42). Knowledge and Space: Vol. 5. Dordrecht: Springer. 
Morgan, K. (2004). The exaggerated death of geography: Learning, proximity and territorial innovation systems. Journal of Economic Geography, 4, 3-21. doi:10.1093/jeg/4.1.3

Ong, A. (1999). Flexible citizenship: The cultural logics of transnationality. Durham: Duke University Press.

Waters, J. L. (2006). Geographies of cultural capital: Education, international migration and family strategies between Hong Kong and Canada. Transactions of the Institute of British Geographers, 31, 179-192. doi:10.1111/j.1475-5661.2006.00202.x

Waters, J. L. (2008). Education, migration, and cultural capital in the Chinese Diaspora: Transnational students between Hong Kong and Canada. New York: Cambria Press.

Waters, J. L., \& Leung, M. (2013a). A colourful university life? Transnational higher education and the spatial dimensions of institutional social capital in Hong Kong. Population, Space and Place, 19, 155-167. doi:10.1002/psp.1748

Waters, J. L., \& Leung, M. (2013b). Immobile transnationalisms? Young people and their in situ experiences of 'international' education in Hong Kong. Urban Studies, 50, 606-620. doi: $10.1177 / 0042098012468902$

Williams, A. (2006). Lost in translation? International migration, learning and knowledge. Progress in Human Geography, 30, 588-607. doi:10.1177/0309132506070169

Open Access This chapter is distributed under the terms of the Creative Commons Attribution 4.0 International License (http://creativecommons.org/licenses/by/4.0/), which permits use, duplication, adaptation, distribution and reproduction in any medium or format, as long as you give appropriate credit to the original author(s) and the source, provide a link to the Creative Commons license and indicate if changes were made.

The images or other third party material in this chapter are included in the work's Creative Commons license, unless indicated otherwise in the credit line; if such material is not included in the work's Creative Commons license and the respective action is not permitted by statutory regulation, users will need to obtain permission from the license holder to duplicate, adapt or reproduce the material. 